\title{
PRELIMINARY NOTE ON A SERIES OF CASES OF LEPROMATOUS LEPROSY TREATED WITH ETISUL
}

\author{
By B. D. MOlesworth \\ (Specialist i/c, Ghana Leprosy Service)
}

A considerable amount of work and experience has been built up in various countries in the use of Etisul by inunction particularly in lepromatous leprosy. Hitherto this work has been limited by the high cost of the drug but a liquid form is now available at a very much reduced cost.

In general our small series of 22 cases in Ankaful Leprosarium in Ghana confirmed the findings hitherto reported, namely a rapid fall in the number of solid forms of M.leprae in the smears followed by a slower reduction in the bacillary index which, however, was well in advance of the reduction obtained in similar cases treated with DDS alone. There was definite clinical improvement and a very remarkable absence of "reactions" even in cases which had hitherto proved intractable.

At the start of the series untreated cases were selected and all received 5 grammes of Etisul thrice weekly in addition to their routine treatment with oral DDS $100 \mathrm{mg}$. daily.

Two cases, both boys, who did produce an acute exacerbation of ENL with dermatitis were receiving DPT (Ciba 1906). This was withdrawn and after the reaction had subsided, Etisul plus DDS were started with no untoward results. Both these cases were so debilitated and their leprosy so acute that Ciba 1906 had originally been chosen in preference to DDS for fear of precipitating further reaction.

Two other cases are worth special note in that they had had already three and five years treatment respectively with a very stormy history of repeated ENL and neuritis both so severe and frequent that no effective anti-leprosy treatment had been possible. Etisul was given and produced a rapid improvement and the dose of DDS was gradually increased to $100 \mathrm{mg}$. daily. Neither case at the time of writing has had any further neuritis or ENL and both have shown marked clinical improvement with a fall of bacteriological index from 2.5 to 0.75 , and 2.1 to 1.3 respectively.

Ulnar neuritis occurred in one case, unfortunately not reported by him, with the result of an early clawing of the 4th and 5th fingers of that side.

Etisul treatment was very popular and the idea of "rubbing in the medicine" on the affected spots seemed entirely logical to the 
patients. The smell worried the staff much more than the recipients.

After nine months' experience with Etisul as a cream, a liquid form was sent to us for trial. Five of the original series were changed to the new form and seven new patients were admitted to this second series.

Bottles containing $250 \mathrm{cc}$. of the liquid were supplied, thus instead of tubes, a five-gramme dose was dispensed to the patient from a graduated measure supplied with each bottle. We found old penicillin vials were ideal for receiving the dose, dispensing was quick and easy and there was little or no wastage.

All patients liked the treatment and the old cases were unanimous in preferring the oily form which they said was easier to rub in; once more it was only the staff who complained about the smell.

Nearly all mentioned a burning sensation after inunction but were not worried by it, in fact they felt it did them good. Three cases stated they felt feverish following inunction but this was not confirmed by the thermometer. One case developed a dermatitis which subsided and although it occurred again after the second inunction did not do so after the third, otherwise there were no complications of any severity other than occasional mild ENL.

\section{Results}

Of the 22 cases in the trial 21 have shown improvement, some very marked. This improvement must not be confused with a welloiled appearance following treatment.

Twenty-one have shown a reduction in the bacteriological index though in one other case this was only very slight. With true lepromatous cases we have not yet achieved a negative in the year of the trial. The improvement in the bacteriological index ranged from $75 \%$ down to $0 \%$ with the average $40 \%$.

Solid forms of $M$. leprae which, in the untreated cases were often as high as $90 \%$, disappeared from the smears in as little as one month but in two cases a few $(5 \%)$ recurred sporadically for as much as ten months. The average time was three months.

Six cases showing most marked improvement (over $60 \%$ ) in the bacterial index were found to have a blood sulphone level of 0.4 mgm. per cent or over, and though a low blood sulphone level did not preclude a good response, three cases showing least improvement had levels below $0.25 \mathrm{mg}$. per cent.

\section{Conclusions}

We feel from this series that Etisul is an extremely useful additive to sulphone therapy producing a more rapid clinical and bacteriological improvement with minimal intolerance or reactional episodes.

Its effectivity appears dependant on an adequate blood sulphone level. The liquid form, at its much lower cost, gives the possibility 
of wider use, especially if the total time of treatment is reduced thereby with the possibility of shortening the period of infectivity of positive cases.

\section{Acknowledgement}

I would like to thank the Chief Medical Officer, Ministry of Health, for permission to publish this note and Imperial Chemical Industries Ltd. for the generous supplies of Etisul; also Mr. J. A. K. Yankah, A.M.I.L.T., i/c of the Laboratory at Ankaful Leprosarium for his careful and detailed work involved by this series.

\section{References}

Browne, S. G., Leprosy Review, 32, 2. April 1961. pp.83-84.

Davies, G. E., and Driver, G. W. (1960), Leprosy Review, 31, 52.

Davey, T. F., and Hogierzell., L. M., (1958), Proc. VII Internat. Congr. Leprol., Tokyo, November.

Davey, T. F., (1959), Leprosy Review, 30, 141-152.

LeChat, M. F., (1960), Leprosy Review, 31, 265.

Ross, C. M., (1960), Leprosy Review, 31, 260.

MCGReGor, H., Leprosy Review, 32, 36.

Davison, A. R., Leprosy Review, 32, 40. 